\title{
Dietary Fat Intake - A Global Perspective
}

\author{
I. Elmadfa M. Kornsteiner \\ Institute of Nutritional Sciences, University of Vienna, Vienna, Austria
}

\author{
Key Words \\ Docosahexaenoic acid - Eicosapentaenoic acid · Fat intake • \\ Fatty acids $\cdot$ Linoleic acid
}

\begin{abstract}
Background/Aim: The objective of this review was to collect data on the dietary intake of total fat and saturated (SFA), monounsaturated (MUFA) and polyunsaturated fatty acids (PUFA), especially linoleic (LA), $\alpha$-linolenic (ALA), eicosapentaenoic and docosahexaenoic fatty acids, in adults from various countries and to compare them with current recommendations for fat intake. Methods: Weighted mean intake data were collected from national dietary surveys, large cross-sectional studies and/or studies with focus on health and nutrition. Thereof, only studies with diet recalls, weighing records or food frequency questionnaires were considered. Results: Data from 28 countries were included, representing Africa (3), America (4), Asia (5), Australia/New Zealand (2) and Europe (14). Total fat intake ranged from 11.1 (China, Guangxi Bai Ku Yao and Han populations) to 50.7 (rural dwellers in Nigeria) percentages of total energy (\%E). SFA intake varied from 3.1 (China, Guangxi Bai Ku Yao and Han populations) to $25.4 \%$ (rural dwellers in Nigeria). Mean MUFA and PUFA intake ranged from 3.5 (China, Guangxi Bai Ku Yao and Han populations) to 22.3 (Greece), and 3.3 (India) to $11.3 \% \mathrm{E}$ (Taiwan), respectively. The mean intake of LA and ALA was between 2.7 (India) and 7.2 (Austria), and 0.4 (France) and 1.0\%E (Finland). Conclusion: With regard to recommendations for fat intake, no general advice for improvements can
\end{abstract}

be given worldwide. Due to different dietary patterns, only regionally specific recommendations can be made about what would be necessary to modify and improve fat quantity and quality of the diet. Copyright $\odot 2009$ S. Karger AG, Basel

\section{Introduction}

Coronary heart disease (CHD) is a major contributor to morbidity and mortality worldwide. Risk factors are sedentary lifestyle, overweight/obesity, smoking, high blood pressure, raised total cholesterol, low-density-lipoprotein (LDL) cholesterol and triglycerides, as well as type 2 diabetes [1]. In brief, high intake of saturated (SFAs) and trans fatty acids (TFAs) as a percentage of total energy intake $(\% \mathrm{E})$ is known to correlate with $\mathrm{CHD}$ due to raised LDL cholesterol levels [2]. A recent pooled analysis of 11 cohort studies has suggested that replacing fatty acids (FAs) with polyunsaturated fatty acids (PUFAs) instead of monounsaturated fatty acids (MUFAs) or carbohydrates prevents coronary heart diseases [3]. However, the type of carbohydrate was not identified in this study [3]. In addition, it is also recognized that commercial foods labeled as 'low-fat/fat-free', which are high in refined carbohydrates and sugars, do not prevent the increasing trend towards obesity and type 2 diabetes [2]. Moreover, low-fat, high-carbohydrate diets are known to reduce the 'good' high-density lipoprotein (HDL) cholesterol and raise triglycerides. Both are associated with an

\section{KARGER \\ Fax +4161306 1234 \\ E-Mail karger@karger.ch}

www.karger.com
(C) 2009 S. Karger AG, Basel

$0250-6807 / 09 / 0545-0008 \$ 26.00 / 0$

Accessible online at:

www.karger.com/anm
Ibrahim Elmadfa

Institute of Nutritional Sciences, University of Vienna

Althanstrasse $14 / 2 \mathrm{~F}$

AT-1090 Vienna (Austria)

Tel. +431 4277 54901, Fax +43 14277 9549, E-Mail ibrahim.elmadfa@univie.ac.at 
increased CHD risk [4]. The results from the Nurses' Health Study demonstrated that replacing SFAs with unsaturated FAs was inversely related to the risk of $\mathrm{CHD}$ due to beneficial effects on blood lipids [4], whereas total fat intake was not significantly associated with the risk of CHD [4]. High consumption of linoleic acid (LA, 5-10\%E) is regarded to reduce the risk of $\mathrm{CHD}$, which is based on a lowered total/HDL cholesterol ratio [5]. This ratio is considered to be a more specific marker for CHD than LDL cholesterol levels [5]. A number of studies suggested that ALA seems to be similar to LA in decreasing LDL cholesterol levels [6]. In addition, there is also a low biosynthesis of eicosapentaenoic (EPA) and docosahexaenoic acid (DHA) from the parent essential ALA. Especially the intake of both EPA and DHA is inversely related to the risk of fatal (and possibly nonfatal) CHD. The protective tissue levels are reached by an intake of preformed EPA and DHA between 250 and $500 \mathrm{mg} /$ day [7].

Due to different effects on health, the following recommendations for fat intake have been established. Intakes of total fat are recommended from 15 to $35 \% \mathrm{E}$, SFAs $<10 \% \mathrm{E}$, TFAs $<1 \% \mathrm{E}$ and PUFAs from 6 to $10 \% \mathrm{E}$ [8-10].

\section{Methods}

The objective of this review was to gather fat intake data for as many countries as possible to provide a global perspective. The intake data on fat quantity (total fat) and quality (SFAs, MUFAs and PUFAs) in adults were included. In this review, the fat intake data are based on estimates of food purchases and availability. The food balance sheets of the Food and Agricultural Organization of the United Nations (FAO) were excluded. They demonstrate only national trends and facilitate international comparisons. However, they are not suited to consider requirements and intakes with regard to age, sex and ethnic groups. Only individual dietary intake data calculated from 24-hour recalls, weighing records and food frequency questionnaires were included. Therefore, the collected data can only give a rough overview of fat intake in various countries, but are limited to direct comparisons due to the usage of different methods.

Only publications from the past 15 years were considered. Data were collected via internet and the electronic database PubMed between July 2008 and February 2009. The following key words were used: intake or diet of total fat, saturated fatty acids, polyunsaturated fatty acids, linoleic acid, $\alpha$-linolenic acid, eicosapentaenoic acid, docosahexaenoic acid, essential fatty acids, omega-6 and omega-3 fatty acids, long-chain polyunsaturated fatty acids, and the name of the country included in title and abstract. The search strategy was limited to the English and German languages.

In most publications included in this review, results were presented as means. Some data had to be recalculated because they were given in absolute amounts; they were then related to and ex- pressed as the percentage of fat energy in total energy intake $(\% \mathrm{E})$. When only the results of subgroups were presented, a weighted mean was used to give an overview for this country. This was done by weighting the mean fat intake of each subgroup by the number of individuals in the subgroup.

\section{Results}

\section{Intake Data}

Intake data were found for 28 countries. Three countries were from Africa, four from America, five from Asia, 14 from Europe and one each from Australia and New Zealand. All reports/publications provided data on total fat intake, SFAs, MUFAs and PUFAs, with the exception of Nigeria (only total fat and SFAs). An overview of the characteristics of the surveys found for each of the countries is presented in table 1 . The data of 10 countries were obtained from the European Nutrition and Health Report 2004 [11], which included intake data on total fat, SFAs, MUFAs and PUFAs from mainly national dietary surveys. Fourteen countries provided additional specific data on LA and ALA, and for 12 countries intake data on EPA and DHA were available.

\section{Fat Intake - A Global Perspective}

Mean daily intake of total fat expressed as percentage of energy ranged from 11.1 to $50.7 \% \mathrm{E}$ (table 1). The highest variation in total fat intake was observed in Africa (13.1-50.7\%E). However, America (25.7-37.2\%E), Asia $(11.1-35.6 \% \mathrm{E})$ and Europe $(28.5-46.2 \% \mathrm{E})$ also demonstrated great differences in regional fat intakes (table 2).

Total fat intake of 15 countries (Canada, Costa Rica, Mexico, US, China, India, Japan, South Korea, Australia, Finland, Italy, Norway, Portugal, Sweden and the UK) was between 20 and 35\%E. Nine countries, the USA (Alaska), Taiwan, New Zealand, Austria, Denmark, France, Germany, Hungary and Spain, demonstrated high fat intakes $(\geq 35 \% \mathrm{E})$. In addition, very high fat intakes $(>40 \% \mathrm{E})$ were observed in Cameroon, Belgium, Nigeria and Greece, while total fat intake in China (Guangxi Bai Ku Yao and Han populations) and Tanzania is $\leq 15 \% \mathrm{E}$.

Eight countries had a lower SFA intake than $10 \% \mathrm{E}$, ranging from 3.1\%E (China: Guangxi Bai Ku Yao and Han populations) to $9.5 \% \mathrm{E}$ (Portugal). The remaining countries had a higher SFA intake $(10.0-25.4 \% \mathrm{E})$ than the recommended $<10 \% \mathrm{E}[8,10]$. The highest SFA intake $(25.4 \% \mathrm{E})$ was observed in rural dwellers in Northern Nigeria, whereas urban dwellers ate only $5.7 \% \mathrm{E}$ of SFAs. The region comparison demonstrated that SFA intake was 
Table 1. Overview of mean intakes (\%E) of total fat, SFAs, MUFAs and PUFAs and characteristics of the surveys from various countries

\begin{tabular}{|c|c|c|c|c|c|c|c|c|c|c|}
\hline $\begin{array}{l}\text { Country and } \\
\text { reference }\end{array}$ & Abbr. & $\begin{array}{l}\text { Year } \\
\text { of publ. }\end{array}$ & Data source & $\begin{array}{l}\text { Sample } \\
\text { size }\end{array}$ & Dietary method & $\begin{array}{l}\text { Age } \\
\text { group }\end{array}$ & $\begin{array}{l}\text { Total } \\
\text { fat, } \% \mathrm{E}\end{array}$ & $\begin{array}{l}\text { SFA } \\
\% \mathrm{E}\end{array}$ & $\begin{array}{l}\text { MUFA } \\
\% \mathrm{E}\end{array}$ & $\begin{array}{l}\text { PUFA } \\
\% \mathrm{E}\end{array}$ \\
\hline \multicolumn{11}{|l|}{ Africa } \\
\hline Cameroon [15] & $\mathrm{CM}$ & 2000 & $\begin{array}{l}\text { habitual diet study of rural and } \\
\text { urban subjects in Cameroon }\end{array}$ & 1,785 & 24-hour recall and FFQ & $24-74$ & 42.8 & 14.1 & 16.4 & 5.9 \\
\hline Nigeria [16] & NG & 2004 & $\begin{array}{l}\text { study of urban and } \\
\text { rural dwellers in northern Nigeria }\end{array}$ & $\begin{array}{l}135 \\
115\end{array}$ & $\begin{array}{l}4 \times 24 \text {-hour recalls and FFQ } \\
\text { and } 7 \text { day dietary record }\end{array}$ & $20-75$ & $\begin{array}{l}37.9 \\
50.7\end{array}$ & $\begin{array}{r}5.7 \\
25.4\end{array}$ & - & - \\
\hline Tanzania [17] & $\mathrm{TZ}$ & 1997 & $\begin{array}{l}\text { food consumption in rural and } \\
\text { urban Tanzania }\end{array}$ & 105 & 24-hour recall & $35-44$ & 13.1 & 4.1 & 4.7 & 4.0 \\
\hline \multicolumn{11}{|l|}{ America } \\
\hline Canada [18] & $\mathrm{CA}$ & 2004 & $\begin{array}{l}\text { nutrition survey, Canada excluding } \\
\text { territories }\end{array}$ & 18,820 & 24-hour recall & $19+$ & 31.4 & 10.2 & 12.5 & 5.6 \\
\hline Costa Rica [19] & CR & 2002 & $\begin{array}{l}\text { comparison of dietary intakes in rural, } \\
\text { suburban and urban populations }\end{array}$ & 503 & FFQ & $\sim 57$ & 32.1 & 11.2 & 12.0 & 5.5 \\
\hline Mexico [20] & MX & $\begin{array}{l}\text { in } \\
\text { prep. }\end{array}$ & $\begin{array}{l}\text { MHNS (Mexican Health an Nutrition } \\
\text { Survey) } 2006\end{array}$ & 15,951 & $\begin{array}{l}\text { FFQ (data are expressed } \\
\text { as medians) }\end{array}$ & $19-69$ & 25.7 & 7.4 & 7.2 & 4.4 \\
\hline US [21] (a) & US (a) & 2008 & (NHANES) nutrition survey & 4,423 & $2 \times 24$-hour recall & $20+$ & 33.7 & 11.3 & 12.4 & 7.1 \\
\hline US Alaska [22] (b) & US (b) & 2005 & $\begin{array}{l}\text { GOCADAN (Genetics of Coronary } \\
\text { Artery Disease in Alaska Natives) Study }\end{array}$ & 734 & $\begin{array}{l}\text { FFQ (data are expressed } \\
\text { as medians) }\end{array}$ & $17-60$ & 37.2 & 12.2 & 14.3 & 6.7 \\
\hline \multicolumn{11}{|l|}{ Asia } \\
\hline China [23] (a) & $\mathrm{CH}(\mathrm{a})$ & 2007 & $\begin{array}{l}\text { INTERMAP (International Study of } \\
\text { Macro- and Mironutrients and Blood } \\
\text { Pressure) Study }\end{array}$ & 839 & 24-hour recall & $\sim 49$ & 20.0 & 5.0 & 8.1 & 5.8 \\
\hline China [24] (b) & $\mathrm{CH}(\mathrm{b})$ & 2007 & $\begin{array}{l}\text { dietary intake of Guangxi Bai Ku Yao } \\
\text { and Han populations }\end{array}$ & 2,343 & 24-hour recall & $15-89$ & 11.1 & 3.1 & 3.5 & 4.3 \\
\hline India [25] & IN & 2005 & survey, only women & 200 & $3 \times 24$-hour recall & & 26.7 & 10.6 & 6.0 & 3.3 \\
\hline Japan [23] & $\mathrm{JP}(\mathrm{b})$ & 2007 & $\begin{array}{l}\text { INTERMAP (International Study } \\
\text { of Macro- and Miro- nutrients and } \\
\text { Blood Pressure) Study }\end{array}$ & 1,145 & 24-hour recall & $\sim 49$ & 24.9 & 6.6 & 9.0 & 6.4 \\
\hline South Korea [26] & $\mathrm{KR}$ & 2004 & $\begin{array}{l}\text { contribution of specific foods to fat } \\
\text { and fatty acids }\end{array}$ & 224 & $\begin{array}{l}\text { FFQ and 3-day dietary } \\
\text { record }\end{array}$ & $30-85$ & 21.1 & 6.0 & 7.7 & 5.1 \\
\hline Taiwan [27] & TW & 1994 & government employees & 423 & 24-hour recall & $40-59$ & 35.6 & 8.8 & 12.6 & 11.3 \\
\hline \multicolumn{11}{|l|}{ Australia } \\
\hline Australia [28] & $\mathrm{AU}$ & 1998 & National Nutrition Survey & 10,851 & 24-hour recall and FFQ & $19+$ & 32.5 & 12.7 & 11.8 & 5.0 \\
\hline New Zealand [29] & $\mathrm{NZ}$ & 1999 & National Nutrition Survey & 4,636 & 24-hour recall and FFQ & $15+$ & 35.0 & 15.0 & 12.0 & 5.0 \\
\hline \multicolumn{11}{|l|}{ Europe } \\
\hline Austria [30] & $\mathrm{AT}$ & 2009 & Austrian Nutrition Survey 2008 & 2,123 & 24-hour recall & $19-64$ & 37.3 & 14.6 & 12.6 & 8.0 \\
\hline Belgium [11] & $\mathrm{BE}$ & $2005^{1}$ & Survey $1979-1984$ & 6,870 & 24-hour recall & $25-75$ & 41.5 & 16.5 & 15.0 & 8.5 \\
\hline Belgium [31] & $\mathrm{BE}$ & 2006 & Epidemiological Survey, only women & 641 & 48-hour recall & $18-39$ & 34.3 & 13.7 & 13.1 & 6.0 \\
\hline Denmark [11] & DK & $2005^{1}$ & Survey 1995 & 1,352 & 7-day record & $19-64$ & 36.3 & 15.2 & 11.0 & 5.0 \\
\hline Finland [11] & FI & $2005^{1}$ & Survey 2002 & 2,007 & 48-hour recall & $25-64$ & 33.7 & 13.9 & 11.2 & 5.0 \\
\hline France [11] & FR & $2005^{1}$ & Survey 1994-2002 & 8,202 & 24-hour recall & $35-60$ & 38.2 & 15.6 & 14.0 & 5.0 \\
\hline Germany [32] & $\mathrm{DE}$ & 2003 & EPIC Cohort & 4,021 & 24-hour recall & $35-40$ & 37.6 & 15.7 & 12.8 & 6.5 \\
\hline Greece [11] (a) & GR (a) & $2005^{1}$ & EPIC Cohort & 20,942 & FFQ & $25-64$ & 46.2 & 13.1 & 22.3 & 6.6 \\
\hline $\begin{array}{l}\text { Greece }[33] \\
(\text { Cretan })(b) \\
\end{array}$ & GR (b) & 1999 & $\begin{array}{l}\text { food and nutrient intake of } \\
\text { Cretan adults }\end{array}$ & 470 & validated 24 -hour recall & $18-64$ & 40.3 & 11.8 & 19.8 & 5.1 \\
\hline Hungary [11] & $\mathrm{HU}$ & $2005^{1}$ & Survey 1992-1994 & 2,349 & $3 \times 24$-hour recall & $18-54$ & 37.9 & 14.0 & 15.0 & 4.0 \\
\hline Italy [11] & IT & $2005^{1}$ & Survey 1994-1996 & - & 7-day record & $18-64$ & 34.0 & 10.0 & 13.0 & 5.0 \\
\hline Norway [34] & $\mathrm{NO}$ & 1998 & $\begin{array}{l}\text { Norwegian national nutrition } \\
\text { surveys } 1997\end{array}$ & 3,144 & FFQ & $19-79$ & 31.0 & 12.2 & 10.9 & 5.5 \\
\hline Portugal [11] (a) & PT (a) & $2005^{1}$ & Surveys 1995-1998, 2001 & 972 & FFQ & $>18$ & 30.1 & 9.5 & 12.9 & 5.3 \\
\hline Portugal [42] (b) & PT (b) & 1999 & assessment of food nutrient intakes & 489 & FFQ & $>40$ & 28.5 & 8.9 & 12.4 & 4.9 \\
\hline Spain [11] (a) & ES (a) & $2005^{1}$ & Survey 1990-1998 & 10,208 & $\begin{array}{l}\text { 24-hour recalls, } 3 \text { day } \\
\text { record FFQ }\end{array}$ & $25-60$ & 38.1 & 12.0 & 16.0 & 5.5 \\
\hline Spain [35] (Catalan) (b) & ES (b) & 1999 & Catalan Nutrition Survey & 1,600 & $2 \times 24$-hour recall and FFQ & $18-60$ & 38.0 & 12.8 & 17.2 & 4.6 \\
\hline Sweden [11] & SE & $2005^{1}$ & National Food Survey 1997-1998 & 1,215 & 7-day record & $18-74$ & 34.0 & 14.5 & 12.5 & 5.0 \\
\hline UK [36] & UK & 2003 & $\begin{array}{l}\text { National Diet and Nutrition Survey } \\
\text { adults } 19-64 \text { years }\end{array}$ & 1,724 & 7-day dietary record & $19-64$ & 33.5 & 12.6 & 11.1 & 6.0 \\
\hline
\end{tabular}

TZ: SFA, MUFA and PUFA estimated and calculated from graphs. FFQ = Food frequency questionnaire.

${ }^{1}$ Data from the European Nutrition and Health Report 2004. 


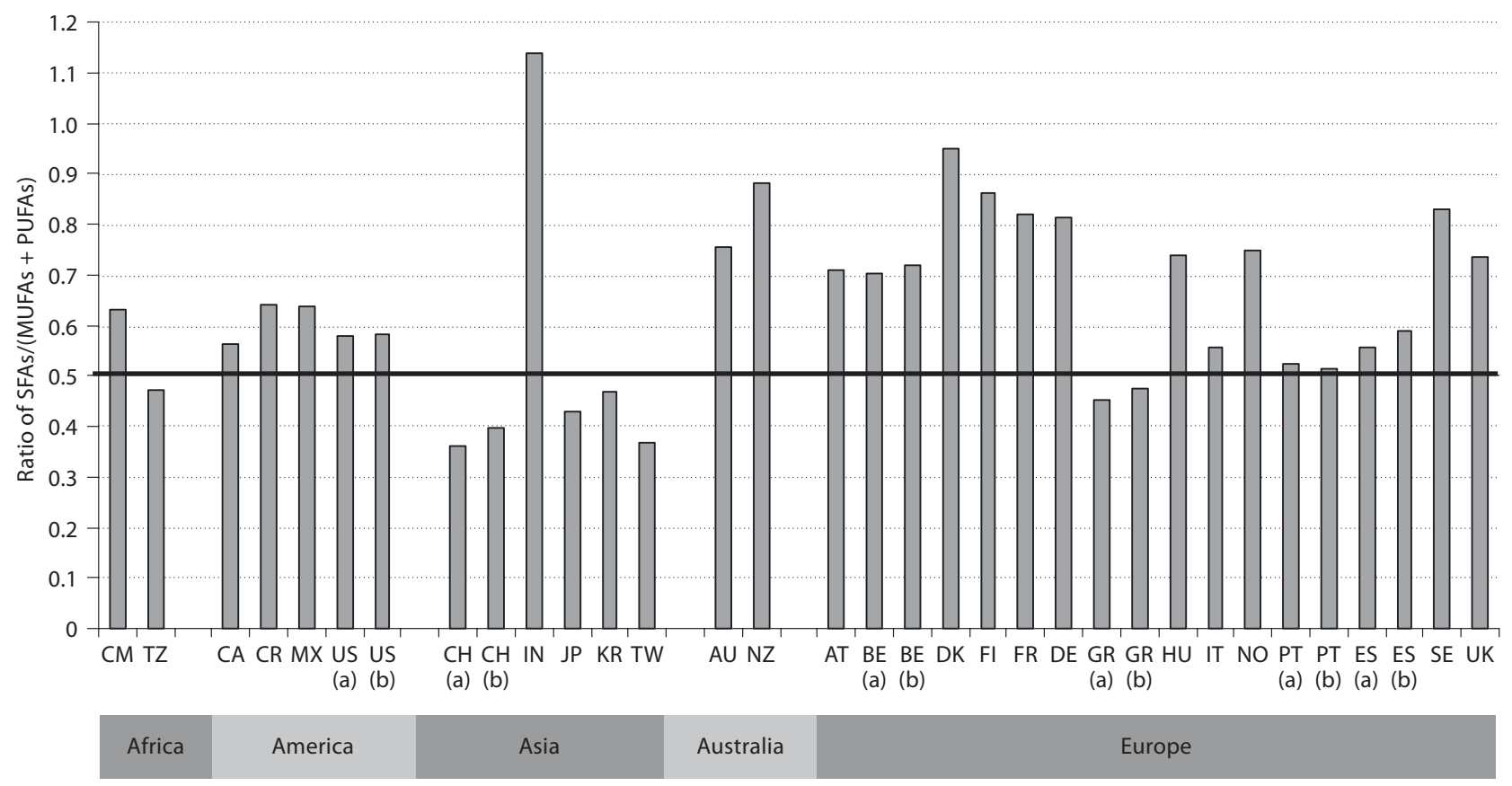

Fig. 1. Ratio of SFAs/(MUFAs + PUFAs) in the diet in different regions. For full country names and references, see table 1.

Table 2. Ranges of intake (\%E) of total fat, SFA, MUFA and PUFA from different continents

\begin{tabular}{llrrl}
\hline Continents & Total fat & \multicolumn{1}{l}{ SFA } & MUFA & PUFA \\
\hline Africa & $13.1-50.7$ & $4.1-25.4$ & $4.7-16.4$ & $4.0-5.9$ \\
America & $25.7-37.2$ & $7.4-12.2$ & $7.2-14.3$ & $4.4-7.1$ \\
Asia & $11.1-35.6$ & $3.1-10.6$ & $3.5-12.6$ & $3.3-11.3$ \\
Australia & $32.5-35.0$ & $12.7-15.0$ & $11.8-12.0$ & 5.0 \\
Europe & $28.5-46.2$ & $8.9-16.5$ & $10.9-22.3$ & $4.0-8.5$ \\
\hline
\end{tabular}

Africa (total fat and SFA: CM, NG and TZ; MUFA and PUFA: $\mathrm{CM}$ and $\mathrm{TZ}$ ).

America (total fat, SFA, MUFA and PUFA: CA, CR, MX and US).

Asia (CH, IN, JP, KR and TW).

Australia (AU and NZ).

Europe (AT, BE, DK, FI, FR, DE, GR, HU, IT, NO, PT, ES, SE and $\mathrm{UK})$.

The full country names and references are shown in table 1. highest in European countries $(11.8-16.5 \% \mathrm{E})$, with the exception of Portugal and Italy $(\leq 10 \% \mathrm{E}$; table 1$)$.

The average proportion of MUFAs was between 3.5 and $22.3 \% \mathrm{E}$. The mean daily intake of PUFAs in populations ranged from 3.3 (India) to $11.3 \% \mathrm{E}$ (Taiwan). Twenty countries demonstrated mean intakes of PUFAs $<6 \%$ E. The ratio of SFAs to the sum of MUFAs and PUFAs [SFAs/(MUFAs + PUFAs)] ranged from 0.36 (China) to 1.14 (India). A ratio $>0.5$ demonstrates that the proportion of SFAs is unfavorable, which could be observed in 21 countries (fig. 1).

Data on LA and ALA intake were limited to 14 countries (USA, Costa Rica, India, Japan, China, South Korea, Australia, Austria, Belgium, Finland, France, Germany, Sweden and the UK). Mean LA intake was between 2.7 (India) and 7.2\%E (Austria). All countries demonstrated higher intakes than the $2.5 \% \mathrm{E}$ of LA that are necessary to prevent deficiency symptoms [10], whereas $9 / 14$ countries did not meet the $\mathrm{WHO} / \mathrm{FAO}$-recommended intake for $\mathrm{n}-6$ (mainly LA) (5-8\%E) [8] (fig. 2). Nine of 14 countries had mean ALA intakes of $\geq 0.5-1 \% \mathrm{E}$ and five countries dem-

Ann Nutr Metab 2009;54(suppl 1):8-14 
Fig. 2. Mean daily intake of LA and ALA among adults in various countries. For full country names, see table 1; US [37]; CR [19]; IN [25]; JP [23]; CH [23]; KR [26]; AU [38]; AT [30]; BE [31]; FI [39]; FR [40]; DE [32]; NO [34]; UK [41].

Fig. 3. Mean daily intake of EPA and DHA among adults in various countries. For full country names, see table 1; US [37]; CR [19]; JP [23]; CH [23]; KR [26]; AU [38]; AT [30]; BE [31]; FR [40]; DE [32]; NO [34]; UK [41].
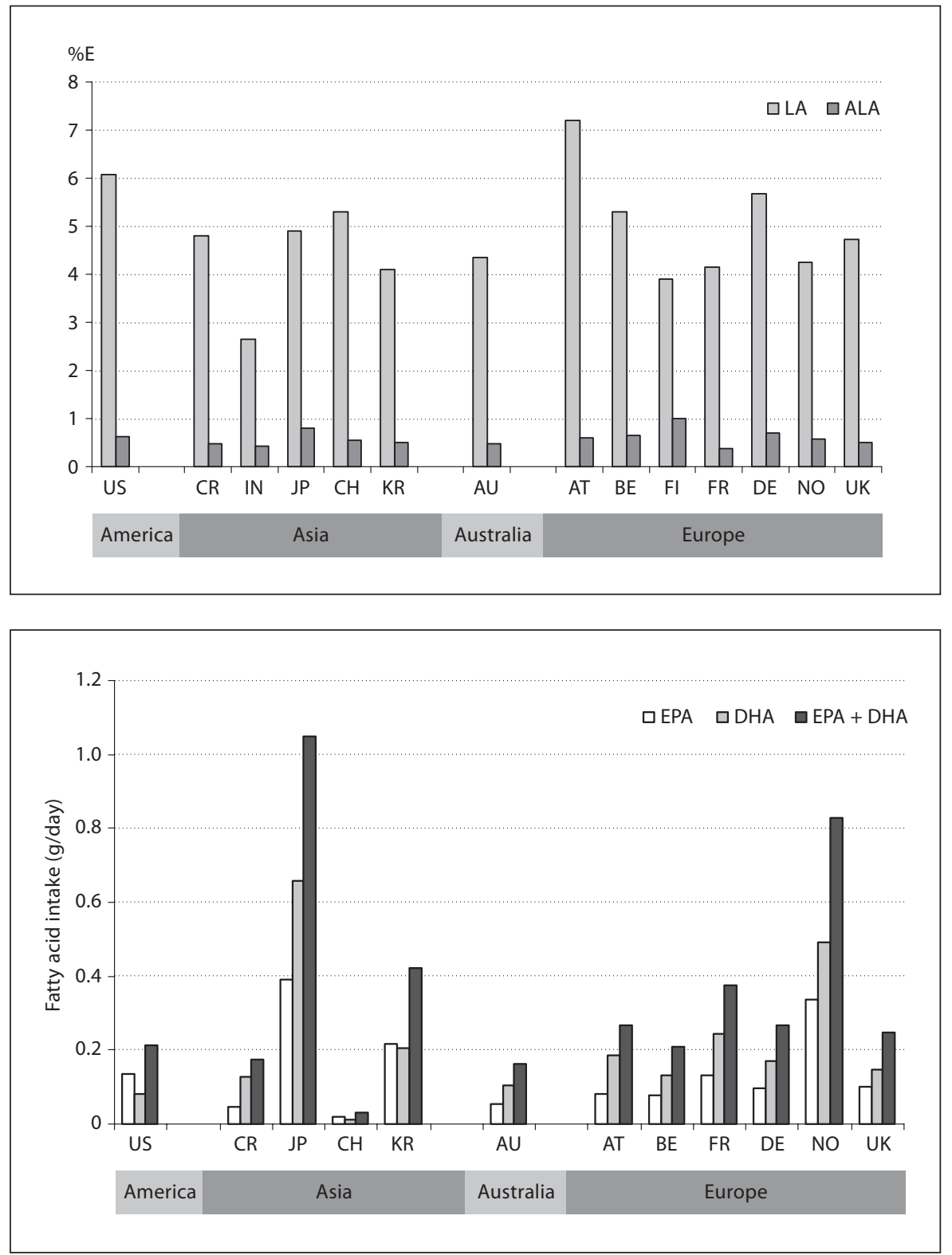

onstrated very low intakes of ALA $(<0.5 \% \mathrm{E})$, which is borderline when it comes to the prevention of deficiency symptoms [10]. The mean intake of EPA and DHA varied between 0.03 (China) and $1.05 \mathrm{~g} /$ day (Japan; fig. 3).

\section{Discussion}

Tremendous differences in total fat and FA intakes were observed between countries from different regions. For instance, 13 countries (Cameroon, Nigeria, US Alas- ka, Taiwan, Austria, Belgium, Denmark, France, Germany, Greece, Hungary, Spain and New Zealand) had total fat intakes $\geq 35 \% \mathrm{E}$, which is higher than recommended $[8,10]$. Total fat intake of six countries was in agreement with the WHO/FAO nutrient intake goals (20-30\%E) [8], including Mexico, China, India, Japan, South Korea and Portugal, while about nine countries were borderline (total fat intake between 30 and $35 \% \mathrm{E}$ ). It has to be emphasized that there is no uniform recommendation for this higher range of total fat intake between 30 and $35 \% \mathrm{E}$, especially in populations with a sedentary lifestyle $[8-10$, 
12]. Total fat intake was even below the recommendation $(\leq 15 \% \mathrm{E})$ [8] in China (Guangxi Bai Ku Yao and Han populations) and Tanzania.

The proportion of SFAs in total fat intake was higher than that of other FA groups in most countries in Europe, America (Mexico), Africa (Cameroon and Nigeria; rural dwellers), Asia (India), Australia and New Zealand. The highest intakes ( $\geq 14 \% \mathrm{E})$ of SFAs were reported in Cameroon, Nigeria, New Zealand, Austria, Belgium, Denmark, France, Germany, Hungary and Sweden. Only eight of 28 countries (Nigeria-urban, Tanzania, Mexico, China, Japan, South Korea, Taiwan and Portugal) had an SFA intake $<10 \% \mathrm{E}$. SFAs, namely lauric, myristic and palmitic acids, are known to increase LDL cholesterol, which is a major risk factor for CHD [13]. Therefore, the upper level for SFA intake is set at 10\%E [8].

The average percentage of MUFAs was between 3.5 and $22.3 \% \mathrm{E}$. The recommendation for MUFAs is calculated as total fat - (SFAs + PUFAs + TFAs) [11]. The replacement of SFAs and TFAs with cis-MUFAs and -PUFAs is negatively associated with CHD [4]. On the one hand, MUFAs are regarded as important FAs to improve the FA pattern by reducing SFAs and TFAs, but on the other hand this is not enough to change the quality of the fat intake when the total fat intake is very high $(>35 \% \mathrm{E})$. For instance, Greece demonstrated a very high intake of MUFAs $(22.3 \% \mathrm{E})$ and total fat intake $(46.2 \% \mathrm{E}$; table 1), and although direct relationships between fat intake and body mass index have to be viewed with caution, a look at the data shows that the mean body mass index in Greek adults ranges from 25.4 (women, age group 2534 ) to 30.3 (women, age group 55-64) [11].

All countries demonstrated higher intakes than $2.5 \% \mathrm{E}$ of LA, which is sufficient to prevent deficiency symptoms. The majority (20) of the countries failed to reach the $\mathrm{WHO} / \mathrm{FAO}$ population nutrient intake goals for PUFA intake $(6-10 \% \mathrm{E})[11]$, which are important for the prevention of chronic diseases (table 1), especially in populations with borderline or even higher total fat intake (30-35\%E). Mainly European countries, but also Australia and New Zealand, fit into this dietary pattern. Twenty countries demonstrated mean intakes of PUFAs $<6 \% \mathrm{E}$. Due to the predominance of SFAs compared to unsaturated FAs, the calculated ratio of SFAs/(MUFAs + PUFAs) was unfavorable $(>0.5)$ in 21 of the 28 countries. The borderline was set according to the general recommendations for fat and FAs ( $<10 \%$ E SFAs, $6-10 \%$ E PUFAs and the remaining from MUFAs 10-15\%E) [8, 10]. Asia demonstrates a ratio $<0.5$ with the exception of India. Data from India are limited to women and are not representa- tive for the whole population. Intake data for India are rare, but in 1998, Ghafoorunissa [14] reported that the fat intake in India varied considerably, which can be observed by widespread chronic energy deficiency related to low fat intake up to an increased risk of $\mathrm{CHD}$ in the urban middle- and high-income groups.

All countries demonstrated higher intakes than $2.5 \% \mathrm{E}$ of LA. This level of intake is necessary to prevent deficiency symptoms [10]. In five countries, ALA intakes were well below $<0.5 \% \mathrm{E}$, an intake level which is at the borderline to the prevention of deficiency symptoms [10], especially when the diet is lacking in n-3 long-chain PUFAs. Data on the mean intake of EPA and DHA were only available from 12 countries. The sum of both FAs varied between 0.03 (China) and $1.05 \mathrm{~g} /$ day (Japan; fig. 3).

\section{Conclusion}

Except for the fact that more accurate intake data are required to assess present global fat intake, available data indicate a very heterogeneous picture regarding current quantity and quality. Africa reveals a very high diversity in total fat, ranging from 13.1 to $50.1 \% \mathrm{E}$. In addition, these variations are not only found between countries in Africa, they are also found within a state (e.g. urban and rural dwellers in Northern Nigeria). Similar observations can be made for Asia, due to the fact that quantity and quality can differ hugely. All considered European countries mostly have high fat intakes $(>35 \% \mathrm{E})$. Especially the intake of SFAs is high $(>10 \% \mathrm{E})$. Therefore, the reduction in saturated fat (from animal products) would reduce both total fat and SFA intake, while the ratio of SFA to unsaturated FAs would be improved. Only Japan, South Korea and Norway demonstrate higher intakes of longchain $\mathrm{n}-3$ fatty acids ( $>0.4 \mathrm{~g} /$ day), which are recognized to have health benefits.

\section{Disclosure Statement}

The data presented here was partially supported by the University of Vienna, the Austrian MOH (Austrian Nutrition Report 2008) and the European Commission, Health and Consumer Protection Directorate General (European Nutrition and Health report, Grant Agreement No. SPC.2002356). 


\section{References}

$>1$ De Backer G: New European guidelines for cardiovascular disease prevention in clinical practice. Clin Chem Lab Med 2009;47:138142.

- 2 Hu FB, Manson JE, Willett WC: Types of dietary fat and risk of coronary heart disease: a critical review. J Am Coll Nutr 2001;20:5-19.

$\checkmark 3$ Jakobsen MU, O’Reilly EJ, Heitmann BL, Pereira MA, Balter K, Fraser GE, Goldbourt U, Hallmans G, Knekt P, Liu S, Pietinen P, Spiegelman D, Stevens J, Virtamo J, Willett WC, Ascherio A: Major types of dietary fat and risk of coronary heart disease: a pooled analysis of 11 cohort studies. Am J Clin Nutr 2009;89:1425-1432.

$\checkmark 4 \mathrm{Hu} F B$, Stampfer MJ, Manson JE, Rimm E, Colditz GA, Rosner BA, Hennekens $\mathrm{CH}$, Willett WC: Dietary fat intake and the risk of coronary heart disease in women. N Engl J Med 1997;337:1491-1499.

$\checkmark 5$ Harris WS: Linoleic acid and coronary heart disease. Prostaglandins Leukot Essent Fatty Acids 2008;79:169-171.

6 Wijendran V, Hayes KC: Dietary n-6 and n-3 fatty acid balance and cardiovascular health. Annu Rev Nutr 2004;24:597-615.

7 Harris WS, Mozaffarian D, Lefevre M, Toner CD, Colombo J, Cunnane SC, Holden JM, Klurfeld DM, Morris MC, Whelan J: Towards establishing dietary reference intakes for eicosapentaenoic and docosahexaenoic acids. J Nutr 2009;139:804S-819S.

8 WHO: Diet, Nutrition and the Prevention of Chronic Diseases. WHO Technical Report Series 2003. Geneva, WHO, p 916.

9 Institute of Medicine: Dietary Reference Intakes for Vitamin C, Vitamin E, Selenium, and Carotenoids (2000). Washington, Institute of Medicine, 2000.

10 D-A-CH: D-A-CH-Referenzwerte. Referenzwerte für die Nährstoffzufuhr. Frankfurt, Umschau/Braus, 2000.

11 Elmadfa I, Weichselbaum E (eds): European Nutrition and Health Report 2004. Forum Nutr. Basel, Karger. 2005, vol 58, pp 34-35.

12 Eurodiet: European Diet and Public Health: The Continuing Challenge. Working Party 1: Final Report. http://eurodietmeduocgr/ 2000.

13 Katan MB, Zock PL, Mensink RP: Effects of fats and fatty acids on blood lipids in humans: an overview. Am J Clin Nutr 1994 60(6 suppl):1017S-1022S.

$\checkmark 14$ Ghafoorunissa: Requirements of dietary fats to meet nutritional needs and prevent the risk of atherosclerosis - an Indian perspective. Indian J Med Res 1998;108:191-202.

$\checkmark 15$ Mennen LI, Mbanya JC, Cade J, Balkau B, Sharma S, Chungong S, Cruickshank JK: The habitual diet in rural and urban Cameroon. Eur J Clin Nutr 2000;54:150-154.

$\checkmark 16$ Glew RH, Conn CA, Vanderjagt TA, Calvin CD, Obadofin MO, Crossey M, Vanderjagt DJ: Risk factors for cardiovascular disease and diet of urban and rural dwellers in northern Nigeria. J Health Popul Nutr 2004; 22:357-369.
17 Mazengo MC, Simell O, Lukmanji Z, Shirima R, Karvetti RL: Food consumption in rural and urban Tanzania. Acta Trop 1997;68: 313-326.

18 CCHS2.2: Canadian Community Health Survey Cycle 2.2, Nutrition (2004). A Guide to Accessing and Interpreting the Data. http://www.hc-sc.gc.ca/fn-an/surveill/nutrition/commun/cchs_guide_escc-eng.php (accessed January 2009, 2004).

19 Kabagambe EK, Baylin A, Siles X, Campos $\mathrm{H}$ : Comparison of dietary intakes of microand macronutrients in rural, suburban and urban populations in Costa Rica. Public Health Nutr 2002;5:835-842.

20 Barquera S, Hernandez-Barrera L, CamposNonato I, Espinosa J, Barriguete JA, Rivera Y: Energy and nutrient consumption in adults: analysis of the Mexican Health and Nutrition Survey (MHNS), in preparation.

21 NHANES: What We Eat in America, NHANES, 2005-2006. www.ars.gov/ba/bhnrc/ fsrg (accessed January 2009).

22 Nobmann ED, Ponce R, Mattil C, Devereux R, Dyke B, Ebbesson SO, Laston S, MacCluer J, Robbins D, Romenesko T, Ruotolo G, Wenger CR, Howard BV: Dietary intakes vary with age among Eskimo adults of Northwest Alaska in the GOCADAN study, 2000-2003. J Nutr 2005;135:856-862.

23 Ueshima H, Stamler J, Elliott P, Chan Q, Brown IJ, Carnethon MR, Daviglus ML, He K, Moag-Stahlberg A, Rodriguez BL, Steffen LM, Van Horn L, Yarnell J, Zhou B: Food omega-3 fatty acid intake of individuals (total, linolenic acid, long-chain) and their blood pressure: INTERMAP study. Hypertension 2007;50:313-319.

24 Ruixing Y, Qiming F, Dezhai Y, Shuquan L, Weixiong L, Shangling P, Hai W, Yongzhong Y, Feng H, Shuming Q: Comparison of demography, diet, lifestyle, and serum lipid levels between the Guangxi Bai Ku Yao and Han populations. J Lipid Res 2007;48:26732681.

25 Goyal U, Sadana B, Verma S: Contribution of various foods to fat and fatty acids intake among urban and semi-urban women of Punjab. J Hum Ecol 2005;18:217-220.

26 Kim J, Kim YJ, Ahn YO, Paik HY, Ahn Y, Tokudome Y, Hamajima N, Inoue M, Tajima $\mathrm{K}$ : Contribution of specific foods to fat, fatty acids, and cholesterol in the development of a food frequency questionnaire in Koreans. Asia Pac J Clin Nutr 2004;13:265-272.

27 Lyu LC, Shieh MJ, Posner BM, Ordovas JM, Dwyer JT, Lichtenstein AH, Cupples LA, Dallal GE, Wilson PW, Schaefer EJ: Relationship between dietary intake, lipoproteins, and apolipoproteins in Taipei and Framingham. Am J Clin Nutr 1994;60:765-774.

28 McLennan W, Podger A: Nutritonal Nutrition Survey. Nutrient Intakes and Physical Measurements. http://www.abs.gov.au/ AUSSTATS/abs@nsf/DetailsPage/ 480501995? OpenDocument (accessed January 2009).
29 NNS97: NZ Food: NZ People. Key Results of the 1997 National Nutrition Survey. http:// www.moh.govt.nz/moh.nsf/0/8f1dbeb1e0e1c70c4c2567d80009b770/\$FILE/nns. pdf (accessed January 2009).

30 Elmadfa I, Freisling H, Nowak V, Hofstädter D: Austrian Nutrition Report 2008. Vienna, University of Vienna, Institute of Nutritional Sciences, 2009.

-31 Sioen IA, Pynaert I, Matthys C, De Backer G, Van Camp J, De Henauw S: Dietary intakes and food sources of fatty acids for Belgian women, focused on n- 6 and n-3 polyunsaturated fatty acids. Lipids 2006;41:415-422.

32 Linseisen J, Schulze MB, Saadatian-Elahi M, Kroke A, Miller AB, Boeing H: Quantity and quality of dietary fat, carbohydrate, and fiber intake in the German EPIC cohorts. Ann Nutr Metab 2003;47:37-46.

33 Moschandreas J, Kafatos A: Food and nutrient intakes of Greek (Cretan) adults. Recent data for food-based dietary guidelines in Greece. Br J Nutr 1999;81(suppl 2):S71-S76.

34 Johansson LR, Solvoll K, Bjorneboe GE, Drevon CA: Intake of very-long-chain n-3 fatty acids related to social status and lifestyle. Eur J Clin Nutr 1998;52:716-721.

35 Graca P: Dietary guidelines and food nutrient intakes in Portugal. Br J Nutr 1999; 81(suppl 2):S99-S103.

36 Henderson L, Gregory J, Irving K, Swan G: The National Diet and Nutrition Survey: Adults Aged 19 to 64 years. Energy, Protein, Carbohydrate, Fat and Alcohol Intake. London, TSO, 2003. http://www.statistics.gov. uk/downloads/theme_health/NDNS_V2. pdf (accessed January 2009).

37 NHANES: What We Eat in America, NHANES, 2001-2002. http://www.ars.usda. gov/SP2UserFiles/Place/12355000/pdf/usualintaketables2001-02.pdf (accessed January 2009).

38 Meyer BJ, Mann NJ, Lewis JL, Milligan GC, Sinclair AJ, Howe PR: Dietary intakes and food sources of omega- 6 and omega-3 polyunsaturated fatty acids. Lipids 2003;38:391398

39 Paturi M, Tapanainen H, Reinivuo $\mathrm{H}, \mathrm{Pi}$ etinen P (eds): The National FINDIET 2007 Survey. Helsinki, Department of Health Promotion and Chronic Disease Prevention, 2008.

40 Astorg P, Arnault N, Czernichow S, Noisette N, Galan P, Hercberg S: Dietary intakes and food sources of n-6 and n-3 PUFA in French adult men and women. Lipids 2004;39:527535.

41 Bakewell L, Burdge GC, Calder PC: Polyunsaturated fatty acid concentrations in young men and women consuming their habitual diets. Br J Nutr 2006;96:93-99.

42 Graca P: Dietary guidelines and food nutrient intakes in Portugal. Br J Nutr 1999; 81(suppl 2):S99-S103. 